\title{
THE ROLE OF INTERNAL CONTROL SYSTEM IN ISLAMIC MICROFINANCE COOPERATIVES FOR MICRO AND SMALL ENTERPRISES
}

\author{
LIYU ADHI KASARI SULUNG \\ UNIVERSITAS INDONESIA
}

The lack of knowledge and the weakness in control and monitoring systems are two problems that hamper the majority of Islamic Microfinance Cooperative institutions (IMC) in Indonesia. To solve this problem, this study aims to discover a proper scheme of credit-risk management that is applicable to several IMCs in different areas. Furthermore, this study also investigates the role of internal control systems in organizing operational risks. Conducting in-depth interviews (IDI) and focus group discussions (FGD) in Jakarta, West Java, and South Sulawesi, this study employs content analysis to understand the scheme of credit-risk management and the hierarchy of intensity of internal control levels. It reveals the general scheme of credit risk management in Islamic microfinance in Indonesia. It also reveals the loan repayment behavior by internal control order.

Keywords: credit risk management, internal control system, Islamic microfinance, micro and small enterprises, poverty, qualitative study

\section{Introduction}

The world is facing poverty and low incomes, which are the biggest threats to sustainable community development. Poverty is a widely-spread world problem that particularly afflicts developing countries (Shirazi and Khan, 2009). In Indonesia, poverty has been a major problem. Based on statistics from Indonesia of March 2014, in urban and rural areas, there are 28.28 million people live below the poverty line of $\mathrm{Rp}$. 302,735 or US\$24.93 per capita per month. Even though the poverty rate shows a decreasing trend, from $24.2 \%$ in 1998 to around $11.25 \%$ in 2014, fighting poverty has a long way to go. 
Providing credit access to low-income people is an attempt to eradicate poverty. It enables them to improve their standard of living by utilizing productive assets. However, the risk-perception of low-income people becomes a barrier to their accessing commercial credit. Their inability to provide collateral exposes them as high-risk borrowers and makes their credit proposals non-bankable (Dusuki, 2008). Another barrier is the lowincome problem of the poor that elevates the risk of providing credit to them (Adams and Vogel, 1986; Sinclair, 1998). Moreover, on the socioeconomic side, illiteracy may also contribute to the barrier of gaining access to credit (Dusuki, 2008; Bennett et al., 1996). These barriers are generally regarded as common factors of the financial market failure in developing countries in the context of the demand (low-income) side (Dusuki, 2008).

This risk-perception of low-income people as high-risk borrowers obliges financial service institutions to create innovative strategies to reduce default risk, or to achieve higher repayment rates for this clientele group. The group-based lending approach is a well-known lending product that provides financial funds to low-income people through collective liability. In addition, Ghatak (1999) also shows how joint liability embedded in this method affects the group formation of borrowers by substituting physical collateral. This approach, usually called social collateral, is used as an incentive to achieve higher repayment rates for group lending than for individual lending (Besley and Coate, 1995).

Many papers show that the joint liability approach is an excellent means for reducing default risk or to yield high repayment rates (Grameen, 2000; Yunus, 2004; Besley and Coate, 1995; Ghatak, 1999). According to Stiglitz (1990), group-lending creates a model of peer monitoring, within which the functions of monitoring and information acquisition are largely transferred from financial institutions to group borrowers and savers (Dusuki, 2008). The function of monitoring is therefore well described in joint liability in the context of group borrowers. However, these research findings have different results from Wydick's (2000) and Fukuyama's (2001) findings. They claim that this social capital or joint liability can cause negative externalities. Fukuyama (2001) also reveals that this happens when people in power lead other members into cronyism and nepotism.

There are very few papers that describe the function of management capacity in keeping low probability of default risk and maintaining high repayment rates. Muhammad (2004) explains that operational riskmanagement is a vital instrument in solving IMCs sustainability by applying the prudent concept of financing delivery. Therefore, there 
should be a system to organize operational risk that is embedded in Islamic microfinance cooperatives (IMC). Seibel (2008) recommends a system of prudential regulation and effective supervision to collect loans from borrowers in Islamic cooperatives. Moreover, he states that focusing on effective internal control is one of the instruments to reassess a participatory process that becomes the challenge and realistic opportunity to reduce operational risk. Hence, Wardiwiyono (2012) argues that bad financing can be prevented by conducting a proper internal control system through detecting error and irregularities in IMC operation.

Because there are only a few papers that study the function of internal control systems in Islamic microfinance cooperatives that organize operational risk, it is imperative to understand the scheme of credit risk management and the role of internal control systems that reduce the default risk probability of "high risk borrower" based on management capacity. To overcome the barriers of 'high risk borrower' perception, this paper aims to discover a proper scheme of credit risk management that is relevant to several IMCs in Indonesia. Furthermore, to reduce default probability of the low-income people, this research also investigates the role of internal control systems in organizing the operational risks in order to yield a high rate of loan-repayment behavior of low-income people.

\section{Literature Review and Shariah Cooperative Background}

\section{Islamic Microfinance and Credit Risk Management}

Low-income societies face barriers to accessing financial services of most commercial banks due to their inability to provide collateral as the requirement for lending. Lack of accounting reports from micro- and small-enterprises also becomes another barrier to accessing financial funding from commercial banks. Informational problems arise in these barriers due to the inability of commercial banks to distinguish good and bad borrowers without physical collateral (Sanrego and Antonio, 2013).

Providing access to low-income societies, microfinance cooperatives participate in alleviating poverty through several successful products such as group lending, self-help groups, pawning gold, and many more. Group lending, also known as the women's empowerment group model, received worldwide attention due to its effects on poverty reduction and employment creation strategy (Mago, Hofisi, and Mago, 2013). This approach is applied through substituting physical collateral by social collateral as an element of trust in lending funds to micro- and small-enterprises. Yunus (2003) shows that this approach is a prominent microfinance innovation 
that enhances access by low-income people to non-collateral loans with joint liability. Even though this group-lending model has the implication of high repayment rate, this model still has an embedded risk due to noncollateral lending and poor management quality.

Risk management skills are important ingredients for the growth and sustainability of IMCs, and such skills enhance early detection and correction of problems or actually prevent them from occurring (Mago, Hofisi, and Mago, 2013). Lack of early identification of problems makes risk control a huge challenge. Townsend (1995) and Morduch (1998a) define ex ante and ex post strategies to control risk. Ex ante strategy is a precautionary strategy for dealing with risk, and ex post strategy is for managing loss to reduce the risk.

\section{Internal Control Schemes in Financing Systems}

Muhammad (2004) shows that management in operational risk through applying internal control system (ICS) becomes a vital instrument to ensure the sustainability of by employing prudential concept of financing delivery. Guy et al (1999) state several objectives of the implementation of internal control systems in financing schemes, which are aligned to the Committee on Sponsoring Organization (COSO) references. Furthermore, Wardiwiyono (2012) adjusts these objectives to Islamic compliance in order to provide practical assurance of internal control activities that is aligned to the core objectives of Islamic micro-finance. Those objectives ensure the reliability of financial reporting in terms of financing schemes, fulfilling Islamic compliance regarding laws and regulations of financing schemes, and achieving efficiency and effectiveness in financing operations. Aligning with these objectives, Wardiwiyono (2012) states that the elements of internal control systems are supposed to be applied at every stage of financing schemes such as identification of potential customers, decision-making, and monitoring. In addition, Guy et al. (1999), Meisser (2003), and Arens et al. (2012) reveal five components of internal control system for financing scheme.

Based on COSO (2011), control environment is one of the five elements of ICS that provides the foundations for the other elements. This component establishes the tone of how the organization environment guides its members in accordance with its ethics and integrity values. Arrens et al. (2011) show that with regard to a micro-finance institution's objectives, implementation of the control environment is defined by the availability of the board of directors, codes of ethics, the availability of internal auditors, organizational structure, and job description manual. 
Risk assessment is the second component of ICS that identifies, manages, and analyzes the risk (Meisser, 2003; Arrens et al, 2011). Since the major risk faced by Islamic microfinance cooperatives is non-performing funding (Wardiwiyono, 2012), the risk assessment implementation can reduce non-performing funding by classifying the risk into several levels (Guy et al., 1999; and Wardiwiyono, 2012). In support of microfinance cooperation, the risk assessments, which are Non-performing Loan (NPF) allowance and NPF write-off (Wardiwiyono, 2012), consist of the "5Cs": Customer character, Cash flow for revenue, Capital of borrower, Condition of the economy, and Collateral.

Control activity is the third component of ICS that refers to a policy or procedure of activities to minimize the operational risk. Meisser (2003) shows that the segregation of duties is one of an organization's control mechanisms. For Islamic microfinance cooperatives, this can prevent the existence of improper financing of operations (Wardiwiyono, 2012)

The fourth component is information and communication, which ensures that the accounting process in the organization is valid and reliable (Wardiwiyono, 2012). Since the information and communication components for financing the operation are supposed to be distributed to all IMC members, the implementation of accounting systems and a manual of the accounting system are needed (Guy et al., 1999; Meisser, 2003)

Monitoring is the fifth component that can ensure the achievement of organizational objectives in each activity (Meisser 2003). In financing activity, monitoring plays an important role in the functions of ICS components, since all components will be ineffective without monitoring activity (Guy et al., 1999; Meisser, 2003; Seibel, 2008). Therefore, the financing process should be monitored from beginning to (Wardiwiyono, 2012). The activity of this component includes monitoring of fund utilization through supervision mechanisms such as appointing an external auditor and executing both routine and surprise inspections (Wardiwiyono, 2012). These inspections are well described by the function of frequent collection or repayment. However, research papers in internal control systems, especially in monitoring activity in microfinance cooperatives, have paid scant attention to these recent issues. There are only a few papers that study the role of monitoring in reducing the probability default of microfinance institutions. Armendariz and Morduch (2005) describe the function of frequent repayment offered by micro-finance institutions. Furthermore, they show that frequent repayment schedules increase the quality of microfinance service for borrowers who have difficulty in saving money. 
Gonzalez-Vega et al. $(1997,74)$ show the importance of frequent repayment in maintaining a low rate of default probability, despite the increased transaction costs. Frequent repayment reduces the risk by selecting customers or borrowers willing to repay their loans even if their investments fail (Armendariz and Morduch, 2005). They also explain the requirement of income streams to make sufficient installments.

The approach to savings offered by IMCs is a mechanism for the borrower to obtain access to micro-financial services without engaging with the commercial banking system (Field and Pande, 2008). They argue that this savings approach, which is embedded in frequent repayment method, may improve the trust by loan officers that the client will stay on track with loan repayments. Therefore, this approach may improve clients' repayment capacity in long-term repayments and reduce the likelihood of defaulting. Armendariz and Morduch (2005) also report that higher probability of client default aligns with less frequent repayment in microfinance institutions in Bangladesh.

\section{Methodology}

Since the behavior of risk management in IMC is complex, this study employs a qualitative method by exploring the scheme of credit risk management and the hierarchy of intensity for internal control levels. Clifton and Handy (2001) show that qualitative methods are powerful tools for exploring complexities. Moreover, qualitative methods produce a wealth of detailed data from a small number of individuals (Patton, 1990). Beirao and Cabral (2007) also support these statements by showing the advantage of qualitative methods in observing people's expressions, in their own words, of what is really important to them. Furthermore, they state that qualitative methods can be a valuable way for participants to specify which factors are important to them.

This research was based on three focus group discussions (FGD) and three in-depth interviews (IDI) with boards of directors and office managers. Elements of risk management were obtained from the IDI with boards of directors, and re-confirmation was made by an IDI with the operational manager. Using a qualitative approach, the author gained insights into the variables and then elaborated them to sharpen the contours of scheme of risk management and internal control. 


\section{Participant descriptions}

The participants were stratified based on job status, age, and gender. Based on job status, three groups are defined as below.

Board of directors: appointed members who act on the behalf of the cooperative's members and must actively participate in the cooperative's activities. They delegate responsibility to members and usually are founders of their cooperatives.

Operational managers: senior-level employees who oversee regular operation of the cooperative.

Group participants: group leaders and group members. A group leader organizes members in a group.

Focus group discussions and in-depth interviews were conducted in IMC offices in Depok. The participants were selected as active directors, operational managers, group leaders, and group members. This procedure was implemented to obtain proper information and deep understanding of the problems and variables of credit risk management in IMCs.

This study employed focus group discussions and in-depth interviews with internal managerial participants who were divided into several groups. By age, there were more members under 39. By gender, there were more females (50 participants) than males (14 participants), and they were separated into three different regions. Finally, based on status, there were 13 directors (BOD), nine office managers (operational managers, accounting officers, or marketing staff), and 42 IMC customers. Hence, there were 64 participants, including 20 in West Java, 21 in South Sulawesi, and 23 in Jakarta.

\section{Focus group discussion and interview procedures and analyses}

This study conducted two to four layers of interviews and analyses. First, focus group discussions were conducted with directors in each area. Secondly, after variables and models were obtained from verbatim analyses, the model was reconfirmed by conducting in-depth interviews with operational manager. 
Table 1. Compositions of the Sample

\begin{tabular}{|l|c|c|c|c|}
\hline \multirow{2}{*}{ Descriptions } & \multicolumn{4}{|c|}{ Status categorizations } \\
\cline { 2 - 5 } & $\begin{array}{c}\text { West Java (1 } \\
\text { microfinance } \\
\text { institution) }\end{array}$ & $\begin{array}{c}\text { South } \\
\text { Sulawesi (2 } \\
\text { microfinance } \\
\text { institutions) }\end{array}$ & $\begin{array}{c}\text { Jakarta } \\
\text { (1 } \\
\text { microfinance } \\
\text { institution) }\end{array}$ & Total \\
\hline Age group & 1 & & & 7 \\
\hline$\leq 29$ & 13 & 11 & 10 & 34 \\
\hline $30-39$ & 6 & 8 & 8 & 22 \\
\hline $40-49$ & & & 1 & 1 \\
\hline$\geq 50$ & 2 & 7 & 5 & 14 \\
\hline Gender & 18 & 14 & 18 & 50 \\
\hline Male & & & & \\
\hline Female & 5 & 4 & 4 & 13 \\
\hline Status & 2 & 2 & 5 & 9 \\
\hline BOD & 13 & 15 & 14 & 42 \\
\hline OM & 20 & 21 & 23 & $\mathbf{6 4}$ \\
\hline Customer & & & & \\
\hline Total & & & & \\
\hline
\end{tabular}

Thirdly, the model was presented to managerial participants of IMCs to receive their approval. Finally, interviewing group participants reaffirmed the model that was approved in previous interviews. This approach was used to gain consistency of outcomes and content validity because the most commonly used ways to estimate validity are face validity and content validity (Cutcliffe and McKenna, 2002).

The participants were classified by directors, operational managers, and IMC customers. Even though the sample was relatively small, this study used triangulation to test the consistency. Boeije (2010) reveals that triangulation refers to the examination of a social phenomenon from different angles. Boeije (2010) also explains that the methods of triangulation can reveal varied dimensions of a phenomenon leading up to a layered and thick description of a subject under study. Some key issues that were developed in focus groups are risk management of giving loan, collateral, controlling (before financing, financing, and after financing), and frequency of controlling. The role of moderator was to facilitate, 
record, check, and analyze the consistency of the discussion of participants on some key issues. For interview, the scheme was categorized into credit risk management and controlling of loan repayment behavior. Some of the main questions are: "How do you manage credit risk before giving a loan to a borrower?"; "As an intermediary institution, how do you manage the risk after giving finance to the borrower?"; "Do they have collateral? If not, how do you manage the loan repayment risk?"; "To date, do you think the scheme to give financing is satisfactory?"; "How do you manage the credit risk if the borrower is not able to repay the loan?"; and "How many times a month do you collect the loan?"

After digitally recording and transcribing the audio recordings of focus group discussions and in-depth interviews, the data were coded into several categories and combined to reach the appropriate model. First, the interview transcripts were analyzed line by line into several categories. Then, the models were drawn by making connections between certain categories. This supports the research of Strauss and Corbin (1998) that categories are integrated and refined. Furthermore, the models were shown to several stakeholders to obtain their confirmation on the model. Last, the models were drawn after getting confirmation from the participants.

Finally, internal control variables were partially adopted from Wardiwiyono (2012) and Guy et al (1999), who divide internal control systems into five components: 1) control environment; 2) risk management; 3) control activities; 4) information and communication; and 5) monitoring. The combination of those variables was partially added into pre-financing, financing, and post-financing in order to sharpen the analysis of credit risk management. 
Figure 1. Credit Risk Management Cycle

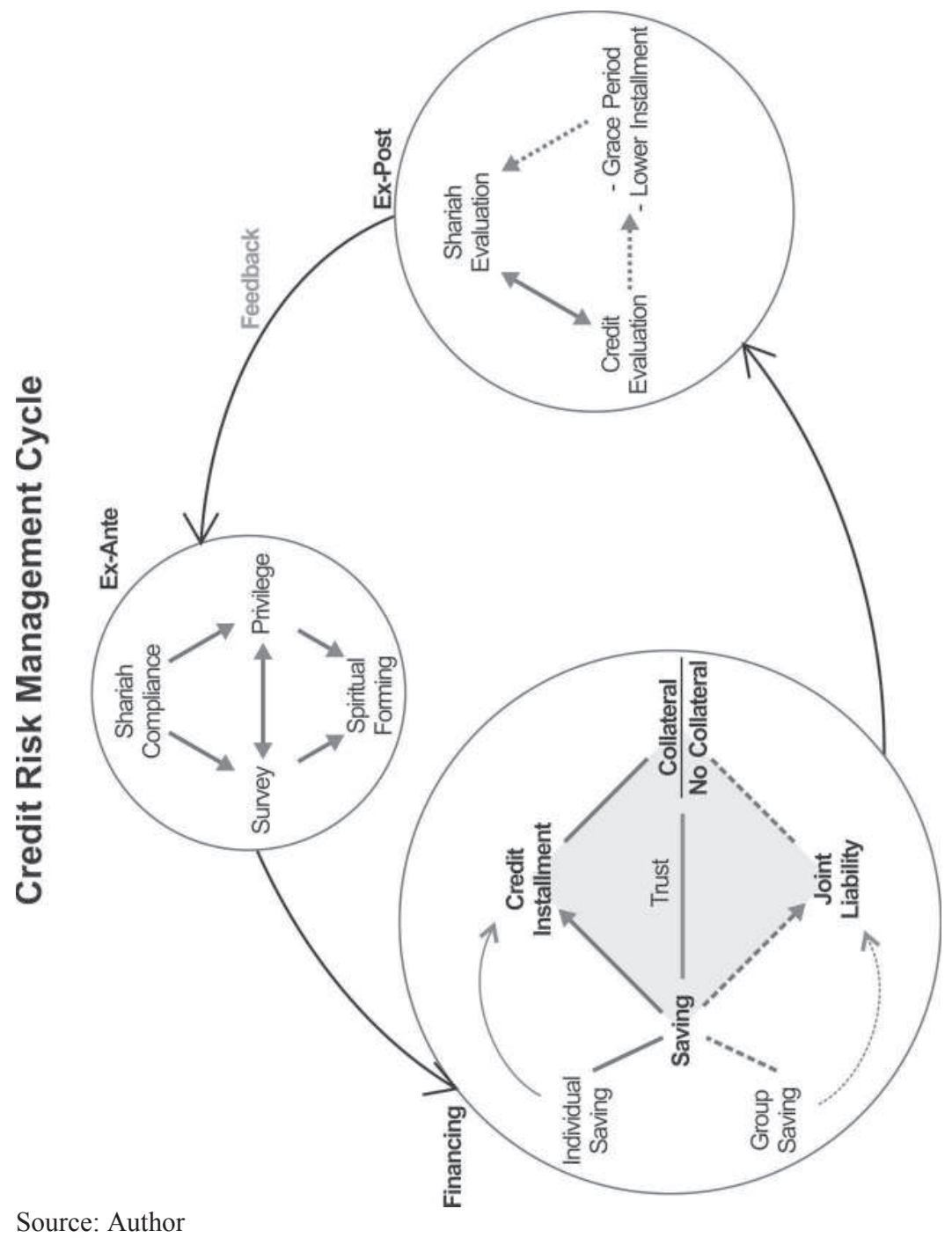




\section{Research Findings}

\section{Risk Management}

From in-depth analysis of risk management systems, this paper reveals the general classification of financing schemes. The general classification of credit periods is divided into pre-financing (ex ante), financing, and post-financing (ex post). Aligning with Townsend (1995) and Morduch (1998a), risk management in these areas contains ex ante financing, and ex post strategies to deal with risk in group-based lending and individual financing (see Figure 1). The pre-financing period (ex ante) occurs before the approval of loan proposals from applicants or a contract agreement among parties. The financing period runs from the provision of funding to the maturity date. Finally, the post-financing period (ex post) runs indefinitely from the maturity date, depending on IMC managerial decisions. According to Wardiwiyono's statement (2012) that the elements of internal control systems are supposed to be applied at every stage of the financing scheme, this paper focuses on identifying potential customers in the pre-financing stage, decision-making in the pre-financing stage, and monitoring in the financing and post-financing stages.

\section{Risk Management of Credit System}

\section{1). Pre-financing (Ex ante)}

At the ex ante stage, most IMCs have relatively similar activity guidelines, both on individual and group-based financing, to avoid the risk of default from borrowers in most of Jakarta, West Java, and South Sulawesi They conduct shariah compliance, surveys, privilege inquiries, and Islamic spiritual teaching. First, the Shariah Supervisory Board has the authority to determine which financial products are allowed to be operated by IMCs, and to ensure those products conform to Islamic teaching. Guy et al. (1999) show that the Shariah Supervisory Board (SSB) is the critical component that gives ethic- and integrity-related guidelines to members of an entity. The SSB is therefore an important factor in determining that all financing products and contracts are operated in line with Islamic laws and education. Based on the results, all IMCs have an SSB to ensure that their financial products are aligned with Islamic principles, which are prohibition of riba (interest), gharar (uncertainty), and maisir (speculation). The goal of appending Islamic principles to the scheme is to build Islamic community development. In West Java and South Sulawesi, group-based lending products have been modified and adjusted to the needs of local characteristics and Islamic compliance. This finding is in line with Davis (2015) who states that stakeholders should understand the role of religious 
teaching on consumer behavior in order to convey better value to them. This modified group lending is based on small groups, which consist of from five to twenty persons. As a female, 43-year-old, director stated:

Our goal is to build community... Other IMCs also applied this kind of group-lending approach... Perhaps they are better than us, but they do not employ spiritual forming.

In Jakarta, the group-lending approach had been applied, but it had a fewer number of groups because of the different characteristics of local social culture.

All IMCs in Jakarta, South Sulawesi, and West Java conduct a survey of the applicants.. A surprise survey is conducted a couple of days after the submission of a loan proposal. Having been practiced for several years, these surveys, observations, and in-depth interviews are conducted to gather authentic information about the applicants, such as customer character, cash flow for revenue, capital of borrower, condition of economic, and collateral (the "5Cs").The $5 \mathrm{Cs}$ complies with the ideas of Meisser (2003), Arrens (2011), and Guy et al. (1999) to identify, manage, and analyze the risk of a client. Furthermore, the classification of the client risk into low, medium, and high levels is conducted in most of the IMCs in all the areas to consider credit proposals. Since micro and small businesses face poor control of financial report estimation (IFAC, 2010), most IMCs identify their cash flow based on revenue instead of profit margin or net income. This simplification of risk assessment component is due to financial illiteracy of micro and small businesses in reporting their financial income. An operational manager stated:

We surveyed door to door, on the spot. We surveyed based on the $5 C s . .$. capacity, character (Male, aged 36, operational manager).

Furthermore, a group leader or IMC staff member's recommendations are appointed as a precaution for group-based or individual lending. For group lending in Depok and South Sulawesi, recommendation for agreement from a group leader is granted to an applicant as a requirement of group membership. Before IMC committees offer financing approval, they will not give financial funding to an applicant if the group leader is not able to offer his or her recommendation. This happens because a group leader will be a risk burden if the borrower has a financing problem. For individual lending, IMCs in Jakarta also use this method to maintain their low, non-performing loans. This personal recommendation is applied as a "social collateral" from a person (group leader or IMC staff-member) to a 
person (borrower) to substitute for physical collateral. In addition, this method is also employed as an element of trust to provide credit access to micro and small entities with non-collateral loans (Yunus, 2003). Regarding personal recommendation, Dusuki (2008) believes that the contract of financing access between lender and borrower will only be honored if the element of trust exists in such transactions.

For the benefit of the group, we have a group leader. If her member proposes a loan, we asked her permission because she will be a risk burden.... (Male, aged 36, operational manager).

Having received a recommendation from a group leader or IMC member of staff, borrowers are invited to join the Islamic group orientation which is organized by an Islamic teacher. This Islamic group orientation is an obligation for those who desire to get acquainted in a group and apply for Islamic financing approval in Depok and South Sulawesi. For individual and group lending, Islamic education also helps participants achieve successful of loan repayment by enhancing their skills and abilities. This concept of exchanging ideas has an impact and is crucial to sharing the experience with others (Krawinkler, 2016). Aiming to deliver the Islamic way to society, most IMCs have some programs such as sustained Islamic education and training to support the achievement of good behavior of loan repayment. There are different approaches to employing this Islamic education among the three areas. In some cities, Islamic education is not obligatory for obtaining financial funding from the IMC. However, applicants are required to participate in sustained training that will influence them in their economic behavior such as daily activities and business operation. This result supports Qardhawi (2004), who explains that Homo Islamicus is required to represent the implementation of Islamic teaching and values. This explains that economic behavior is influenced by Islamic teachings and values. Spielberg (2004) and Umar (2005) also report that economic behavior in economic decisions is not merely affected by rational reasons but also determined by religiosity, culture, and other non-rational reasons. Therefore, Islamic teaching and IMC's training become a method to support its clients to run business and repay loans in Islamic perspective.

IMC aims to deliver the Islamic way to society... So we asked them to participate in a spiritual group in a month... A month before financing provision, they are required to participate in a group (Male, aged 36, operational manager). 


\section{2). Financing period}

After obtaining loan approval from the board of directors, the applicant is able to get financial funding from the IMC. At the financing stage, there are four forces of internal control that affect a borrower's credit worthiness: credit installment, collateral, joint liability, and savings. First, collateral is employed as a means to pledge against risks as a consequence of risk-averse micro finance. There are differences in applying collateral in each area. In Depok, local characteristics influence borrower behaviors of loan repayment, bearing default risk through applying collateral guarantee in several IMCs. Hence, all lending products, both individual and group, are embedded with collateral to protect their assets from default risk. Different results are gained from South Sulawesi and Jakarta. In South Sulawesi, borrowers have access to lending consent without any collateral if they participate in women-based groups. In group lending, IMCs in this region agree to offer lending below $\$ 160$ per individual because the borrower is already burdened with social collateral pressure among group members. However, collateral is required for individual lending to pledge the risk in South Sulawesi. On the other hand, IMCs in Jakarta also have unique characteristics to manage their credit risk in terms of financing methods. For both group and individual lending, the borrower is able to access financial funding below $\$ 240$ without any collateral. Having no collateral, this individual lending method has a different approach to handling default risks by having a recommendation agreement from the IMC's marketing staff. Therefore, the staff also participate as a grantor to offer a trust to low-income people for financial services. The staff are held responsible for their grantee or recommended borrowers in order to maintain high repayment behaviors. This recommendation agreement from the IMC's officer, which is also called personal collateral, social ties, or social collateral, is an element of trust in granting credit access to microand small-entities. It supports the findings of Besley and Coate (1995) and Ghatak (1999), who point out that 'social collateral' schemes embedded in this approach offer a powerful incentive to reach a high rate of loanrepayment from clients. Floro and Yotopolous (2005) report that the strong social ties can improve the loan repayment and loosen up credit constraints.

Based on our local characteristics and experiment, experiment, experiment, we need collateral (Male, aged 36, operational manager, Depok).

Saving, loan installment, and joint liability are the other internal control variables at the financing stage besides collateral. There are 
relationships among these three variables in terms of lending classification for individuals and groups. For individual and group lending, individual saving is required to repay the loan in fixed amounts per period. Most IMCs in the three areas run weekly and daily collections as their loan repayment program. In the case of group lending, IMCs in West Java and South Sulawesi conduct a group meeting once a week to collect the loan. Group members get together weekly to attend Islamic teaching, at which the loan is collected by the group leader. They use individual savings to repay their own loans. In the case of special conditions such as loanrepayment failure, or group activities, they use group savings called kas kelompok (KK), as a micro-insurance if any member fails to meet the loan obligation. This group cash has many benefits. First, it is used to cover loan repayment failure of a group member, which is termed a joint liability. Second, it is applied as savings to help a member in an emergency such as sickness. Finally, this group saving is employed as a group active indicator. Group savings or group cash align with several models used in Bolivia to support loans by savings as a basis for insurance (Chua et al., 2000 in Berglind and Karimi, 2007). Therefore, this approach addresses managerial problems through developing the capacities of borrowers, and enabling them to manage their own funds.

Most IMCs in South Sulawesi and West Java apply individual savings to repay the loan. Accounting officers conduct weekly visits to their group-based home to collect loans in the case of group lending. In addition, credit officers, who are marketing staff in Jakarta, make more regular visits, sometimes daily, to their clients in order to collect repayments. The IMC staff regularly visit the borrower's home or workplace as a free service in order to maintain high repayment behaviors. Having rigidly monitored loan repayments, credit officers become acquainted with their clients through regular face to face collections (Armendariz and Morduch, 2005). This regular monitoring acts as an early warning system to loan officers about any emerging problems.

Savings are a must... because they pay the loan installment by using their savings to make it easy (Male, aged 36, operational manager).

3). Post-Financing (Ex post)

The ex post stage covers the period after the maturity date to provide contract flexibility for borrowers who face payment difficulties. In-depth interviews, routine inspections, and manual accounting systems to special borrowers are the internal control activities at this stage. After being granted a period of grace, the borrower has an opportunity to continue the loan installment of 50 days for daily installments, or six months to a year 
for weekly installments. Most IMCs still apply routine inspections of daily and weekly loan collections as regular monitoring - this can reduce the probability of risk default, which is aligned with Gonzalez-Vega et al $(1997,74)$ who report the value of early warning in frequent repayment or regular monitoring.

In addition, they also lessen the amount of the loan installment by lightening the burden of the borrower's loan repayment obligation. These findings show that the combination of the grace period and lower installment encourages borrowers to repay the loan in the post-financing period. Finally, feedback from shariah evaluation is conveyed to shariah credit compliance.

Then we summoned the borrowers a month after the maturity date, if they had not repaid the loans. If they did not respond to our texts, calls, or memorandums, we had inspectors visit them to discover whether they were bankrupt, sick, divorced, or whatever... We advised them to reschedule the repayment... and to lessen the installment amount to as much they can repay. We do not take their collateral as long as they are willing to pay (Male, aged 36, operational manager).

\section{Internal Control Orders}

Based on the financing stage description, there is no major restriction to deter low-income people from accessing financial lending in most ICSs samples. Therefore, at which stage should ICSs employ strategies to substitute this restriction to tight monitoring activities? The internal control order sorts three stages by using the frequency of routine monitoring or inspections. Those three stages are ex ante (pre-financing), financing, and ex post (post-financing). In order to maintain high repayment behaviors, this method, called an internal control order, aims to find the proper method of IMC strategies. Internal control variables (Table 2) are classified into three stages: ex ante, credit, and ex post stages.

At the ex ante period, surprise inspections for 5Cs and referenceapproval from group leader or marketing staff are usually conducted in a prior session in most of the three areas. In group lending, Islamic group orientation was usually conducted once a week, and this orientation was employed a month before loan provision. Thus, the total frequency of internal control activities for group lending is six times. In individual lending, since there are only one or two sessions of Islamic spirit orientation before loan provision, the total frequency at the pre-financing stage is three to four times (see Table 2). 
Table 2. Intensity of Internal Control Activities at every stage

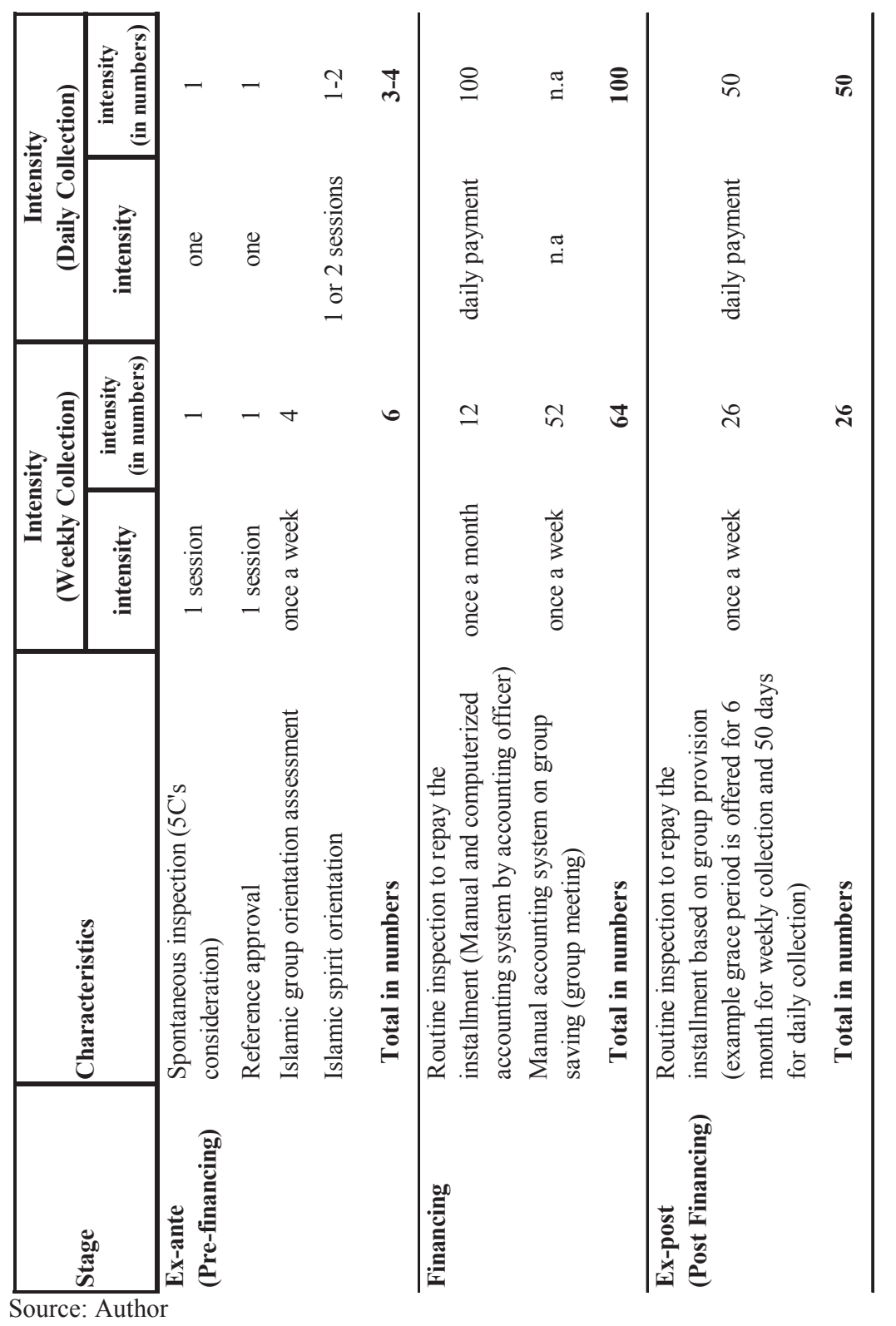


Monitoring activities are key to measuring the sequenced priority of the three stages. This aligns with Guy et al. (1999), Meisser (2003), and Seibel (2008) who show that monitoring plays an important role in the functions of ICS components since all components will not be effective without monitoring activities, including routine inspection by the accounting officer, and manual accounting systems on savings. At the financing stage, most of the participants in this research report daily or weekly collections as their regular inspections. These regular inspections are applied based on Wardiwiyono's (2012) report that customer activity monitoring of utilizing the funds can be conducted by executing routine and surprise inspections as a supervision mechanism of the internal control system in Islamic microfinance cooperatives. In group lending, the accounting officer regularly visits each group once a month to collect the installment. Furthermore, a group meeting was conducted once a week in order to lighten the burden of loan installment by regular savings. Therefore, the total frequency of internal control activities at the financing stage is 64 times a year in weekly collections. To maintain its repayment behaviors, daily collection has a high intensity of monitoring activities to collect the loan within 100 days. Accounting officers regularly visit the borrower's house or shop to serve them in the best way. Therefore, the financing stage has the highest score of intensity of internal control activities compared with the other stages. This tight monitoring of daily inspection of 100 times and weekly inspection of 64 times enable this stage to have the highest frequency of monitoring activities. 
Figure 2. Internal Control Order

\section{Internal Control Order (ICO)}

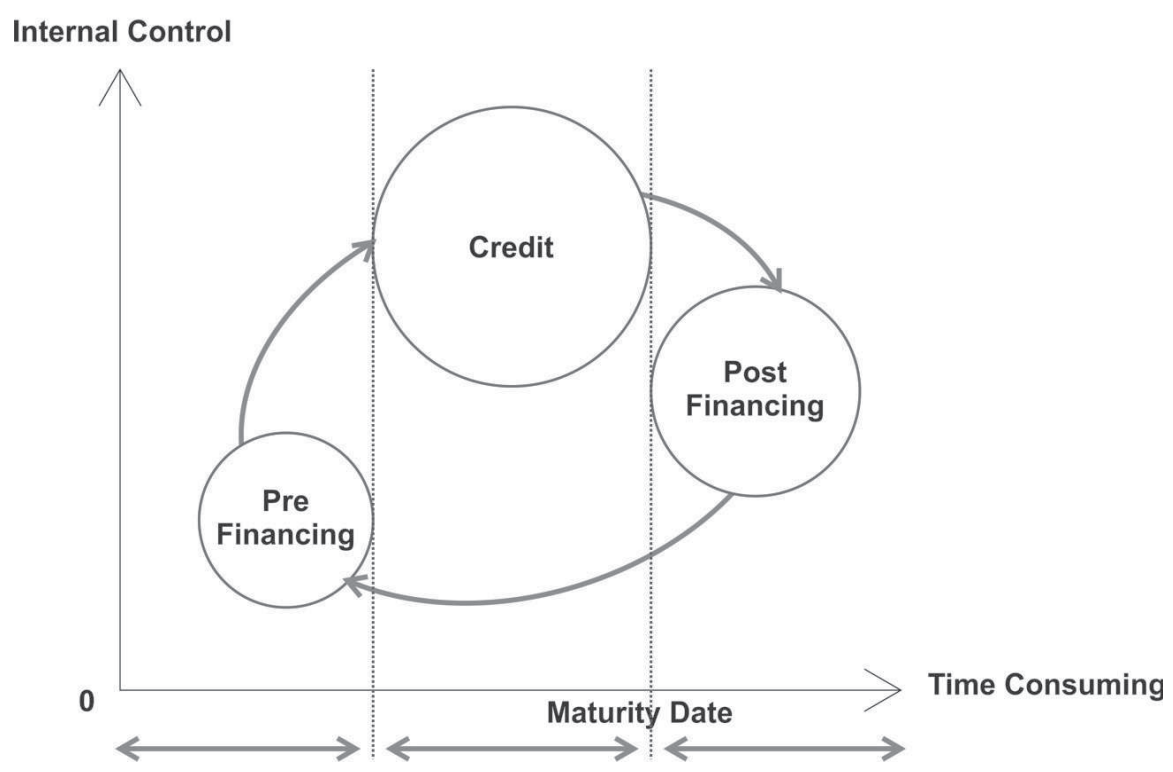

Source: Author

We make a routine visit once a week... as our tagline: serve, close, and easy (Male, aged 36, operational manager).

Since we are just small people, we run our micro-business on a day-to-day basis - that is why we do not have any option but to repay our loan through daily collections to lighten our burden (Female, aged 46, clients).

Finally, regular visits to borrowers after the maturity date are conducted once a week for group lending. Having a grace period of six months, the total frequency of internal control activities in the postfinancing stage is 26 times (see Table 2). In daily inspection, the number of routine visits is 50 , since they extend the expiration date up to 150 days. This tight monitoring after the maturity date puts post-financing as the second priority of having frequent routine inspections. Moreover, most IMCs in the three areas offer the opportunity to extend the repayment 
period long after their due date in order to maintain repayment quality: any repayment is seen as better than a client defaulting, and taking a borrower's collateral is seen only as the last resort. It reduces the amount of the installment, and allows the IMCs to observe the progress of the borrower's loan repayment. In the case of extended repayments, the size of the installment could become bigger or smaller depending on the state of the borrower's business. This should not be confused with charging a higher rate of repayment to borrowers whose business is performing well, with the promise of fewer installments - most borrowers agree to this, hoping that they will earn a higher credit rating once the loan is paid off. loan.

Then, their faith also supports their trust in the borrower repaying the

Even though they have debt of Rp.500 million, if they can just repay Rp.100,000 a week, what we can do? We did not take their collateral as long as they have willingness to pay ... but we also see the progress... The last is du'a (prayer to Allah) that makes the miracle (Male, aged 36, operational manager).

Internal control orders sort these stages on a priority of sequencing. Figure 2 shows the relationship between the intensity of internal control activities and the accumulation of time. The relationship is described in the $\mathrm{x}$ and $\mathrm{y}$ axes: the frequency of the internal control activities in the $\mathrm{y}$-axis and the time accumulation in the $\mathrm{x}$-axis. The chart describes the relationship between both the variables to give priority among the three stages. Based on Table 2 and Figure 2, internal control systems in the financing stage have the first priority in the hierarchy of internal control orders. Monitoring of the entire financing stage period is prominent in weighting this stage as the first priority. The highest weight is given to the financing stage because of daily and weekly monitoring which are used as routine inspections. The more often debt collection occurs within the period, the more weight of intensity the monitoring activities have. This frequent collection is made to lighten the loan repayment burden for micro- and small-enterprises since they obtain daily revenue and run daily businesses. Furthermore, this regular collection is employed to substitute the lack of physical collateral. This frequent collection enhances the ability of low-income people to repay their loan without collateral. Having no collateral, this method plays a remarkable role in ascertaining low-income people to access financial services. It differs from banks that have abundant restrictions to avoid their risks before giving financing services to borrowers such as collateral ownership, minimum wage, fee or revenue, etc. Hence, IMCs employ strategies to substitute these restrictions in the 
pre-financing stage with tight monitoring activities in the financing stage. The result aligns with Armendariz and Morduch (2005) and GonzalezVega et al (1997), who report that regular monitoring can provide an early warning feature to credit officers by providing information about clients. Loan officers become familiar with clients by meeting them regularly. However, this paper reports more rigid monitoring based on daily and weekly routine inspections in individual and group lending instead of Armendariz and Morduch's findings (2005) of regular monitoring based on only weekly repayment and group-based lending. Joint liability embedded in group loans has an advantage over individual loans to give social sanctions or informational flows among the members (Sanrego and Antonio, 2013). This paper also complements another one from Gomez and Santor (2003) and De Aghion, Armendariz, and Gollier (2000) which show the lower default rates and higher repayment rates for group-based lending relative to individual lending by using peer monitoring in group loans. Therefore, in order to reduce the probability of default, this regular monitoring, as one of internal control system components, becomes an innovative tool for both individual and group lending approaches. The intensity of internal control activities places the post-financing stage in the second rank, through a combination of routine inspection and accumulation of time from the pre-financing period to the extended date. Finally, the prefinancing stage in IMCs is placed in the third rank to control risk by avoiding borrower's default risk. This responsibility embraces the $5 \mathrm{Cs}$ in surprise inspection, Islamic group orientation assessment, and reference approval.

\section{Conclusion}

The risk management scheme in the Islamic microfinance credit system consists of three stages: ex ante (pre-financing), financing, and ex post (post-financing). The components of internal control activities should be placed at every stage of the financing system to reduce default probability. This aligns with Wardiwiyono (2012), who explains monitoring as one of the internal control activities that should be conducted from the beginning to the end of the financing process.

In addition, this study shows how IMCs manage loan repayment behavior by dividing the internal control order process into three stages: (1) financing; (2) ex post (post-financing); and (3) ex ante (pre-financing). Each stage requires distinctive risk management, and of the three stages, the first and second are considered the most important. Tight monitoring for the entire period of the financing stage plays a prominent role in 
weighting this stage as the first priority. The highest weight is given to the financing stage because of daily and weekly monitoring which are employed as routine inspections. The more often internal control activities occur within a period, the more weight of intensity a score has. This frequent collection is made to lighten the loan repayment burden for micro- and small-enterprises, since they obtain daily revenue and run daily businesses. Furthermore, these regular collections at the financing and post-financing stage have a remarkable role to substitute restrictions in the pre-financing stage in order to maintain high repayment behaviors from borrowers. Therefore, this paper complements previous papers to place regular monitoring as an important role to reduce the probability of risk default for both individual and group-based lending. This aligns with Armendariz and Morduch (2005) and Gonzalez-Vega et al (1997), who report that regular monitoring is able to provide an early warning by visiting clients face-to-face and knowing about their clients' conditions.

\section{References}

Asian Development Bank. (2000). Finance for the Poor; Microfinance development Strategy. [Online] Available:

www.adb.org/Documents/Policies/Microfinance/financepolicy.pdf. (September 12, 2008).

Berglind,V. and Karimi, A. (2007). "Repayment performance in microfinance: a theoretical analysis" [Online]. Available at: http://www.esays.se [Accessed November 2009].

Boeije, H. (2010). "Quality of the Research", Analysis in Qualitative Research. (1st ed.) Pp. 176-177. London:Sage.

Bryman, A. (2008). "Social research methods", Ln N. Gilbert (Ed.), Researching Social Life. (3rd ed.) Pp. 45-57. London:Sage.

Chua, T. R., Mosley, P., Wright, A. N. G., \& Zaman, H. (2000). Microfinance, risk management and poverty. Study submitted to the Office of Microenterprise development Washington DC: USAID

Clifton, K.J., Handy, S.L. (2001). " Qualitative methods in travel behavior research", Paper presented at the International Conference on Transport Survey Quality and Innovation, Kruger National Park, South Africa, August 2001.

Cutcliffe, J.R., and McKenna, H.P. (2002), "When do we know that we know? Considering the truth of research findings and the craft of qualitative research. International Journal of Nursing Studies. 39: 611618.

Davis, L., and Jai, T.M. (2015) "Effects of religiosity on apparel shopping 
orientation: an exploratory study", International Journal of Business Anthropology, Vol. 5, No: 2, pp. $24-35$

Dusuki, A.W. (2008) "Banking for the poor: the role of Islamic banking in microfinance initiatives", Humanomics, Vol. 24 Iss: 1, pp.49-66

Field,E., Pande R., Papp J., and Rigol, N. (2013). "Does the Classic Micro_nance Model Discourage Entrepreneurship Among the Poor? Experimental Evidence from India", American Economic Review, October 2013, vol. 103 no.6, pp. 2196-2226

Ghatak, M. (1999). "Group lending, local information and peer selection", Journal of Development Economics, vol. 60, no. 1, pp. 27-50

Guy, D.M., Alderman, C.W. and Winters, A.J. (1999). Auditing, 5th ed., The Dryden Press, Fort Worth, TX.

Krawinkler, S.A. (2016). "Teaching aspects of business anthropology ", International Journal of Business Anthropology, Vol. 6, No: 1, pp.95 108

Mago, S., Hofisi, C., and Mago, S. (2013). "Microfinance Institutions and Operational Risk Management in Zimbabwe: Insights from Masvingo Urban", Mediterranean Journal of Social Sciences, Vol. 4 No.3.

Morduch, Jonathan. (1998). "Does Microfinance Really Help the Poor? New Evidence from Flagship Programs in Bangladesh" (June). Cambridge, Mass.: Department of Economics and Harvard Institute for International Development (HIID), Harvard University; Stanford, Calif:: Hoover Institution, Stanford University. (Draft.)

Mu'allim and Abidin. (2005). "The professionalism of IMC's personnel in Yogyakarta", Millah Journal, Vol. 2 No. 2, pp. 67-86.

Muhammad. (2004). The Fund Management of Islamic Bank, Ekonisia, Yogyakarta.

Patton, M.Q.(1990). "Qualitative evaluation and research methods". Sage Publication, Newbury Park, CA.

Sanrego, Y.D., and Antonio, M.S. (2013). "The effect of social capital on loan repayment behavior of the poor(a study on group lending (GLM) application in Islamic microfinance institution)", Journal of Indonesian Economy and Business, Vol. 28, No. 2, pp. 209 - 231.

Seibel, H.D. (2008). "Islamic microfinance in Indonesia: the challenge of institutional diversity, regulation, and supervision", Journal of Social Issues in Southeast Asia, Vol. 23 No. 1, pp. 86103.

Soemitra. (2009). Islamic Banks and Islamic Financial Institutions, Kencana Perdana Media Group, Jakarta.

Shirazi, N.S., and Khan, A.U. (2009). "Role of Pakistan Poverty Alleviation Fund's and Micro Credit in Poverty Alleviation (A case of Pakistan)", Pakistan Economic and Social Review, pp. 215 - 228. 
Stiglitz J.E. (1990). "Peer Monitoring and Credit Markets", The World Bank Economic Review, Vol. 4, No. 3, pp. 351-366

Strauss, A., Corbin, J. (1998). "Basics of qualitative research: Techniques and procedures for developing grounded theory". Sage Publications. Thousand Oaks, CA.

Townsend, Robert M. (1995). "Consumption Insurance: An Evaluation of Risk-Bearing Systems in Low-Income Economies." Journal of Economic Perspectives, vol. 9, no. 3, (Summer): pp.83-102.

Wardiwiyono, Sartini. (2012). "Internal control system for Islamic micro financing :An exploratory study of Baitul Maal wat Tamwil in the City of Yogyakarta Indonesia”, International Journal of Islamic and Middle Eastern Finance and Management, Vol. 5 No. 4., pp. 340-352

Yunus, M. (2003). Banker to the poor. New York: Public Affairs. 